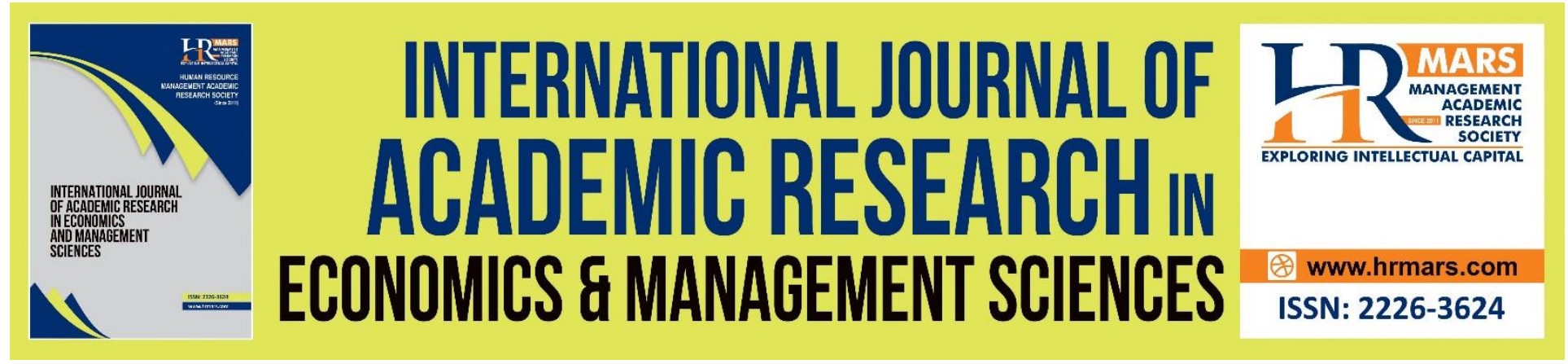

\title{
Insight of Recent Strategies and Initiatives in Managing Integrity in Malaysia
}

Shadiya Mohamed S. Baqutayan \& Siti Hawa Binti Mayati

To Link this Article: http://dx.doi.org/10.6007/IJAREMS/v10-i3/10824

DOI:10.6007/IJAREMS/v10-i3/10824

Received: 01 July 2021, Revised: 25 July 2021, Accepted: 24 August 2021

Published Online: 10 September 2021

In-Text Citation: (Baqutayan \& Mayati, 2021)

To Cite this Article: Baqutayan, S. M. S., \& Mayati, S. H. B. (2021). Insight of Recent Strategies and Initiatives in Managing Integrity in Malaysia. International Journal of Academic Research in Economics and Management and Sciences, 10(3), 271-286.

Copyright: @ 2021 The Author(s)

Published by Human Resource Management Academic Research Society (www.hrmars.com)

This article is published under the Creative Commons Attribution (CC BY 4.0) license. Anyone may reproduce, distribute, translate and create derivative works of this article (for both commercial and non-commercial purposes), subject to full attribution to the original publication and authors. The full terms of this license may be seen

at: http://creativecommons.org/licences/by/4.0/legalcode

Vol. 10, No. 3, 2021, Pg. 271 - 286

http://hrmars.com/index.php/pages/detail/IJAREMS

JOURNAL HOMEPAGE

Full Terms \& Conditions of access and use can be found at http://hrmars.com/index.php/pages/detail/publication-ethics 


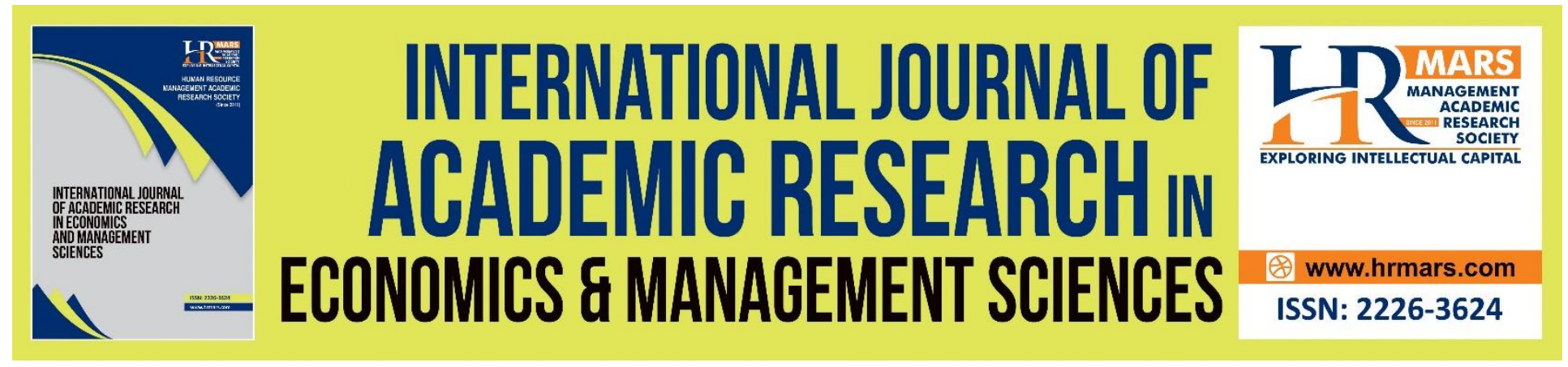

\title{
Insight of Recent Strategies and Initiatives in Managing Integrity in Malaysia
}

\author{
Shadiya Mohamed S. Baqutayan \& Siti Hawa Binti Mayati
}

Razak Faculty of Technology and Informatics, University Technology Malaysia (UTM) UTM, Jalan

Sultan Yahya Petra, Malaysia

Email: Shadiya.kl@utm.my

\begin{abstract}
The Malaysian government has taken several steps to combat corruption and nurture integrity in society, especially among civil servants. There are many key strategies aimed at fostering and enhancing a culture of integrity, thus, the Malaysian government has agreed to align all efforts on governance, dignity, and anti-corruption into a single integrated plan to strengthen anticorruption initiatives. The National Anti-Corruption Plan (NACP) was created and demonstrated to achieve the Sustainable Development Goals (SDG-16) that focuses on Peace, Justice, and Strong Institutions. The purpose of this study is to provide an overview of recent strategies and initiatives in managing integrity in Malaysia and to evaluate the integrity behavior among public sector employees. The online questionnaire surveys were distributed to collect the primary data. About 100 employees were randomly selected among civil servants in Malaysia, and yielded a response rate of $77 \%$ (77 respondents). The data was then analyzed using SPSS to achieve the objectives; thus, descriptive statistics and Pearson correlation were used to analyze the study variables. The finding indicated that there is a significant relationship between anti-corruption plans and managing integrity among employees in Malaysia. This study will help policymakers to take necessary action to ensure the long-term continuity of the policies and action plans implemented to create a corrupt-free nation that values integrity. It will give value in achieving the SDG-16 goal to substantially reduce bribery and corruption in all their forms.
\end{abstract}

Keywords: Sustainable Development Goals, Integrity, Anti-Corruption, Public Sector

\section{Introduction}

The Malaysian government has taken a number of steps to combat corruption and nurture integrity in society, especially among civil servants. There are many key strategies aimed at fostering and enhancing a culture of integrity. This includes the establishment of institutions, the enactment of legislation and changes to existing legislation, and the distribution of campaign materials to encourage strong qualities among civil servants. Nonetheless, civil servants' integrity remains a major concern (Mohamed et al., 2017; Yusoff et al., 2019). Indeed, Mcdermott et al (2019) state the National Anti-Corruption Plan (NACP) was created in line with the Sustainable 
Development Goals (SDG) of the United Nations, demonstrating Malaysia's determination to achieving SDG 16: Peace, Justice, and Strong Institutions, which emphasizes the importance of combating corruption. The aim promotes a commitment to fight corruption, improve accountability, combat illicit financial flows, and improve knowledge access. As a result, the target is vital to the 2030 Agenda as a whole, because corruption disrupts progress on the other SDGs.

According to the World Economic Forum, \$2 trillion wasted annually on corruption could be used to eliminate hunger ( $\$ 116$ billion), cure malaria ( $\$ 8.5$ billion), fix the global infrastructure imbalance ( $\$ 1$ trillion), and offer basic education for children (\$26 billion). Corruption costs money, which means development is denied to those who are especially at risk of falling behind. Sustainable development consists of five pillars that are planet, people, partnerships, prosperity, and peace - which are impacted by corruption. Anti-corruption initiatives are therefore critical in establishing robust, transparent, and accountable institutions capable of meeting the demands of all people (Timilsina, 2019). Moreover, Siddiquee (2011) states leading international organizations such as Transparency International and World Bank have emphasized the implementation of national integrity systems as a viable strategy for combating corruption in recent years. The national integrity scheme, in large part, incorporates the core elements of the different methods. Corruption becomes a high-risk, low-return practice when a clear and efficient national integrity mechanism is in place. The most distinguishing characteristic of the national integrity scheme is that it focuses on preventing corruption rather than prosecuting and punishing criminals.

Despite the numerous measures aimed at enhancing service quality in the public sector, concerns and critiques persist. As a multiracial nation, Malaysia is faced with various threats and hurdles (Rahim \& Omar, 2017). For a long time, complaints of ineffectiveness, bureaucracy, lack of flexibility, low transparency, and weak performance have affected the public sector (Siddiquee, 2006). These cases arouse the public's attention and as a result, would lead to a loss of confidence towards public service delivery. However, it is expected that the government's continuous efforts and decisions will eventually yield results in the future. According to Transparency International's Corruption Perception Index (CPI) for 2020 where out of 180 countries, Malaysia slipped six places from 51 to 57; the decline is concerning, as the index has been trending downward in fields like procurement contracts, deforestation, and leaders' unlawful land sales to foreigners (Sitheravellu, 2021). The purpose of this study is to provide an overview of recent strategies and initiatives in managing integrity in Malaysia and to evaluate the integrity behavior among public sector employees. The findings of this study carry values to the SDG in improving the policy on integrity. This study will help policymakers to take necessary action to ensure the long-term continuity of the policies and action plans implemented to create a corrupt-free nation that values integrity. It will give value in achieving the SDG 16 goal to substantially reduce bribery and corruption in all their forms. 


\section{Literature Review \\ Integrity}

Integrity is derived from the Latin word integer, which means completeness and wholeness. Integrity refers to the truthfulness of an acting entity's views and actions (Palanski \& Yammarino, 2007). Integrity, according to Trevinyo-Rodriguez (2007), is the connection between character (personal psychology) and conduct or behavior (ethics). Integrity is described as a parallel relationship between an actor's word (character) and behavior (conduct). Some researchers characterized integrity as the quality of service in the public interest while adhering to commonly accepted moral principles and norms (Six \& Hubert, 2008). The concept of integrity has been explored in a variety of areas, including ethics, management of human resources, organizational behavior, leadership, and psychology (Bauman, 2013; Trevinyo-Rodriguez, 2007). Integrity or ethical behavior, from an organizational perspective, applies not only of being corrupted or unethical but also related to the value of individual or organizational behavior where it reflects the quality of acting in compliance with the principles, norms, and laws that the society and member of the organization embrace (Bauman, 2013; Kolthoff et al., 2010; Kaptein \& Avelino, 2015).

Aziz et al. (2015) state integrity are essential for building trusting relationships in the boardroom and with stakeholders. The government's major goal is to safeguard the public interest by implementing an effective and efficient governance process that strengthens the protection, exhibits accountability and transparency in operational duties and public service relations (Alam et al., 2019; Said et al., 2016). According to Jones (2019), integrity encourages workers to follow rules and instills principles that support ethical behavior. As a result, the integrity mechanism is critical, and it plays a key function in maintaining transparency and accountability in the organization. Because the public sector serves as an intermediary between the people and the government, it is more important for the public sector to be ethical, transparent, and effective (Maizatul et al., 2016). The government's main aim is to safeguard the public interest by creating an efficient and productive governance system that guarantees citizens' rights, as well as accountability in the performance of everyday tasks by civil servants (Aziz et al., 2015).

\section{Malaysia's Integrity and Anti-Corruption Plan}

As Malaysia moves on its way to becoming a developed and high-income economy nation, the battle against corruption has taken the place of Malaysia's national agenda. The National Integrity Plan (PIN) was introduced in April 2004, as the first of many national initiatives. PIN was created with a concrete strategy in mind, to achieve Vision 2020's objective to build a country with strong values and ethics. In 2010, Government Transformation Programme (GTP) continues the spirit of PIN via National Key Result Areas - Fighting Corruption. GTP believes that to decrease the cost of doing business and remove waste and inefficiency in the government system, corruption must be eliminated. Corruption holds back Malaysia's plan to achieve developed country status by impeding both transformation and economic development. The GTP 1.0 aimed to combat corruption by implementing a variety of broad-based anti-corruption strategies at all levels, from the highest to the lowest. Not only were anti-corruption programs introduced within 
law enforcement agencies but government procurement was also improved in an attempt to combat corruption.

Despite the strategy's favorable outcomes, the government planned that there was still potential for progress in combating corruption in the country. As a result, the GTP 2.0 was introduced to help achieve the desired targets by implementing more targeted programs. The GTP 2.0 acted as a tool for improving and effectively tracking the current programs under the GTP 1.0, as the fight against corruption is a long-term war. Despite this, foreign surveys such as the Global Corruption Barometer and the Corruption Perception Index (CPI) revealed that a large number of Malaysians do not believe the corruption problem has improved. The surveys' findings suggested that the process of transition needed to be reinforced and that more might be done to make people more aware of corruption at all levels, particularly at the initial stages (Kapeli \& Mohamed, 2015). As a necessary consequence, Malaysia's government has committed to integrating all efforts in the areas of integrity, governance, and anti-corruption into a single integrated plan to boost anti-corruption activities (Abdul Rahim et al., 2020; Bandhold, 2003). Following that, on June 8, 2018, the Prime Minister chaired the Cabinet Special Committee on Anti-Corruption (JKKMAR) and decided to establish and develop the NACP to replace the previous PIN. The NACP attempts to establish specific objectives based on initiatives that will be implemented over the next five years to address national issues of integrity, governance, and anti-corruption.

Move ahead, the National Anti-Corruption Plan (NACP) was created to attain the objective of "Malaysia being known for her integrity, not corruption," and to create a corrupt-free nation that embraces accountability and openness. The five-year plan (2019-2023) was developed to convey a strong message to the public about the new government's commitment to reducing and fighting corruption in Malaysia. The NACP is a five-year strategy document that outlines 6 strategies, 17 strategic objectives, and 115 initiatives that will be implemented over the next five years (National Centre for Governance, Integrity, and Anti-Corruption (GIACC), 2019). Taken together, Malaysia has a complex anti-corruption system in place (Sajari et al., 2019). Table 1 shows the efforts taken to achieve several important milestones during this long and arduous path. 
Table 1: Milestones of anti-corruption strategies and initiatives in Malaysia

\begin{tabular}{|c|c|c|}
\hline \multicolumn{2}{|l|}{ Year } & Milestones \\
\hline \multirow{2}{*}{2004} & : & Launching of the National Integrity Plan (NIP) \\
\hline & & Establishment of Institute of Integrity Malaysia (IIM) \\
\hline 2008 & : & Setting up of Malaysian Anti-Corruption Commission (MACC) \\
\hline 2009 & : & $\begin{array}{l}\text { Prime Minister Directive No. 1/2009 - Implementation of Certified } \\
\text { Integrity Unit in Ministries, Departments, and Agencies }\end{array}$ \\
\hline 2010 & : & $\begin{array}{l}\text { Launching of the Government Transformation Programme (GTP) } \\
\text { (National Key Results Area - Fighting Corruption) and Economic } \\
\text { Transformation Programme (ETP). }\end{array}$ \\
\hline 2013 & : & Appointment of Minister of Governance and Integrity \\
\hline 2014 & : & $\begin{array}{l}\text { Prime Minister Directive No. 1/2014 - Establishment of Integrity and } \\
\text { Governance Committee }\end{array}$ \\
\hline 2018 & : & $\begin{array}{l}\text { Formation of the Special Cabinet Committee on Anti-Corruption. } \\
\text { Establishment of the National Centre for Governance, Integrity, and } \\
\text { Anti-Corruption (GIACC). }\end{array}$ \\
\hline 2019 & & Launching of the National Anti-Corruption Plan (2019-2023) \\
\hline
\end{tabular}

\section{Research Methodology}

This study was conducted by distributing online questionnaire surveys to collect the primary data. About 100 respondents were randomly selected from public sector employees in Malaysia and yielded a response rate of 77 percent ( 77 respondents). The online questionnaire used in this study comprises closed-ended questions and is divided into 3 sections. Section A was referring to respondent demographic information that are age, gender, ethnicity, academic qualification, job position, type of workplace, working experience, and job scope. Section B was referring to integrity behavior by using a five-point Likert scale (strongly disagree, somewhat disagree, neutral, somewhat agree, strongly agree). Section $\mathrm{C}$ was referring to the anti-corruption plan statement by using a five-point Likert scale (strongly disagree, somewhat disagree, neutral, somewhat agree, strongly agree).

The questionnaire was developed based on previous studies related to integrity and anticorruption. Questions related to demographics and integrity behavior were adopted from Alam et al (2018); Rosli et al (2015) and Malaysian Integrity System referred to as the Corporate Integrity Assessment Questionnaire. The collected data were analyzed using IBM SPSS Statistics 26. To analyze the research variables, descriptive statistics and Pearson correlation analysis were used. Descriptive statistics are used to examine the data's various parameters. Correlation analysis is used to describe the direction and strength of the linear relationship between two variables.

\section{Findings and Discussion Demographic Profiles}

Respondents were asked to provide demographic information such as age, gender, ethnicity, academic qualification, job position, type of workplace, working experience, and job scope in the questionnaire. The findings and statistics were illustrated as follows: 


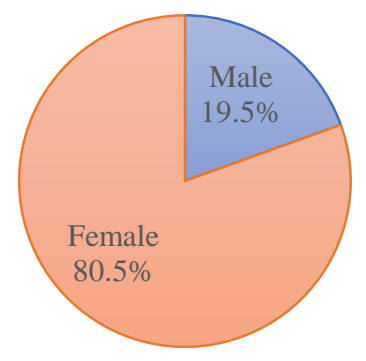

Figure 2: Gender

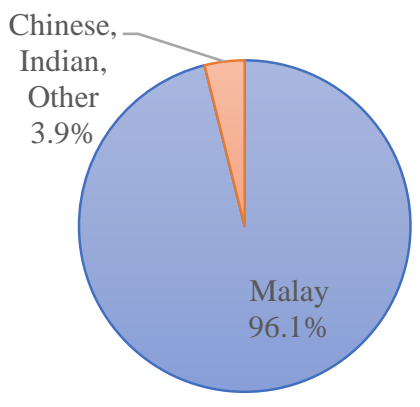

Figure 3: Ethnicity

Of 77 total respondents, 80.5 percent of the respondents are females and 19.5 percent are males (Figure 2). The majority of the respondents are Malays comprising 96.1 percent and the remaining 3.9 percent comprises Chinese, Indian, and other ethnicities (Figure 3).

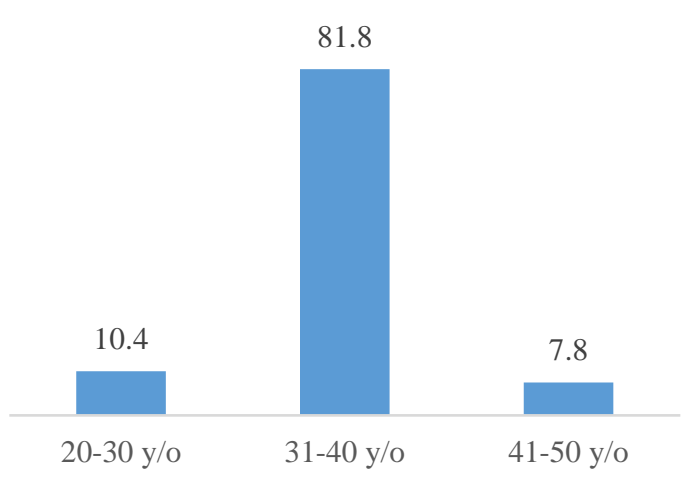

Figure 4: Age group

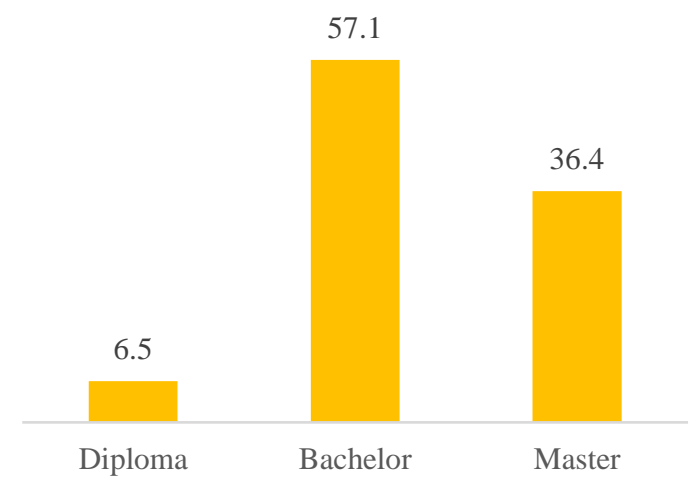

Figure 5: Academic qualification

In total, 81.8 percent of the respondents are in the 31-40 years old age, followed by 10.4 percent and 7.8 percent in the age group of 20-30 years old and 41-50 years old, respectively (Figure 4). It was found that 57.1 percent of the respondents have academic qualifications of a Bachelor's degree, followed by 36.4 percent and 6.5 percent with a Master's and Diploma, respectively (Figure 5). 
INTERNATIONAL JOURNAL OF ACADEMIC RESEARCH ECONOMICS AND MANAGEMENT SCIENCES Vol. 10 , No. 3, 2020, E-ISSN: $2226-3624$ 2020 HRMARS

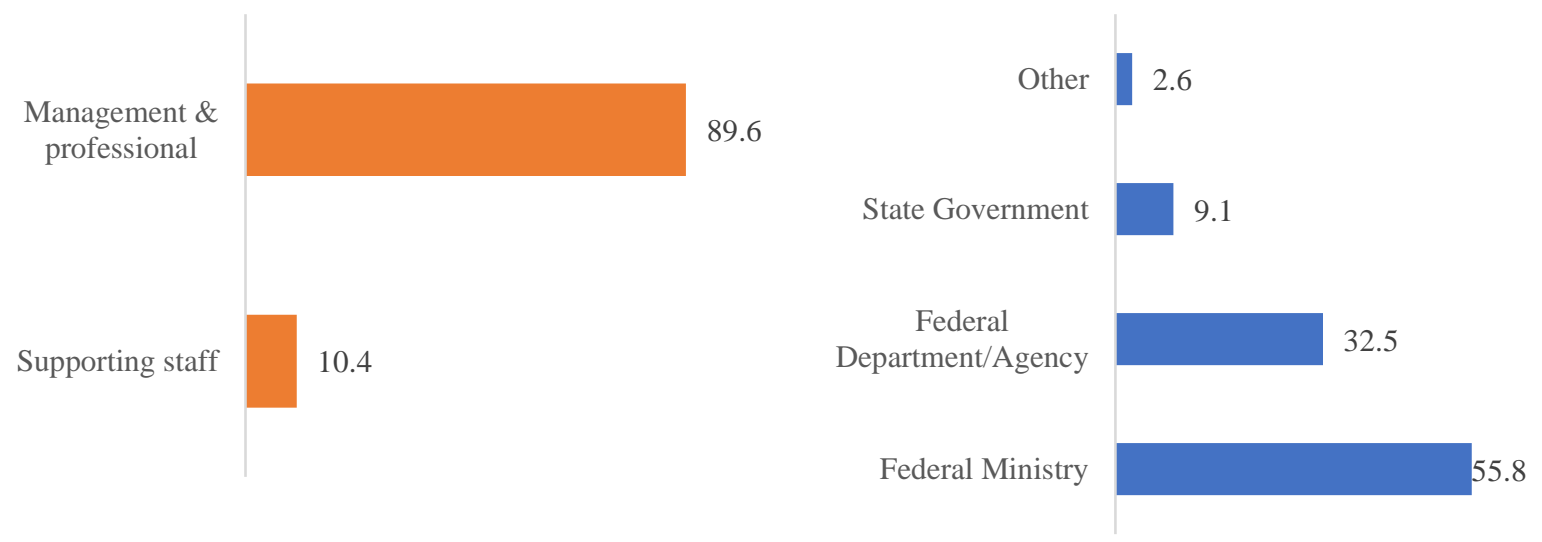

Figure 6: Job position

Figure 7: Workplace

The job position of 89.6 percent of the respondents is management and professionals, while 10.4 percent is supporting staff (Figure 6). In total, 55.8 percent of the respondents working in Federal Ministries, 32.5 percent in Federal Departments and Agencies, and 9.1 percent in State Government. The remaining 2.6 percent are from other departments (Figure 7).
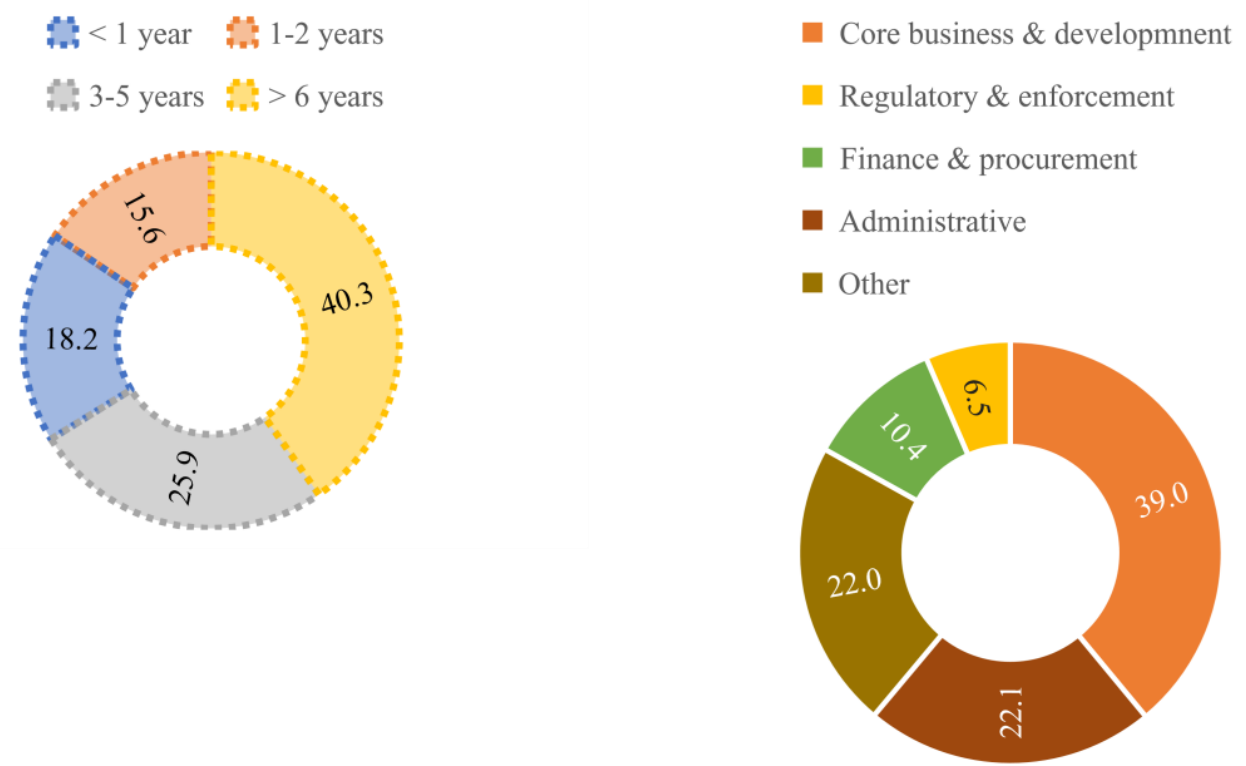

Figure 8: Working experience

Figure 9: Scope of job

Those having more than 6 years of experience in the current organization accounted for 40.3 percent, and 25.9 percent have 3 to 5 years working in the present department. Meanwhile, 18.2 percent are those with less than 1 year and 15.6 percent have 1 to 2 years working experience (Figure 8). In total, 39 percent of the respondents are in the core business and development job related, followed by 22.1 percent in administrative, 10.4 percent in finance and procurement, and 6.5 percent in regulatory and enforcement. The remaining 22 percent are from other various divisions. 


\section{Correlation between Integrity and Anti-Corruption Plan}

The direction and strength of a linear association between two variables are described using correlation analysis. The research question of this study - is there a relationship between the implementation of strategies and initiatives in the anti-corruption plan over managing integrity among public sector employees in Malaysia? Correlation is a concept that represents the relationship between two continuous variables, in terms of and the direction and strength of the interaction.

Table 2: Descriptive Statistics

\begin{tabular}{ll|l|l} 
& Mean & $\begin{array}{l}\text { Std. } \\
\text { Deviation }\end{array}$ & N \\
\hline Integrity & 3.9241 & .69729 & 77 \\
\hline $\begin{array}{l}\text { Anticorruption } \\
\text { plan }\end{array}$ & 4.1677 & .57968 & 77 \\
\hline
\end{tabular}

Table 3: Pearson correlation test between anti-corruption plan and integrity

\begin{tabular}{llll} 
& & & \multicolumn{1}{l}{$\begin{array}{l}\text { Anticorruptio } \\
\mathrm{n} \text { plan }\end{array}$} \\
\hline \multirow{2}{*}{ Integrity } & $\begin{array}{l}\text { Pearson } \\
\text { Correlation }\end{array}$ & 1 & $.511^{* *}$ \\
\cline { 2 - 4 } & Sig. (2-tailed) & & .000 \\
\cline { 2 - 4 } & $\mathrm{N}$ & 77 & 77 \\
\hline \multirow{2}{*}{$\begin{array}{l}\text { Anticorruption } \\
\text { plan }\end{array}$} & $\begin{array}{l}\text { Pearson } \\
\text { Correlation }\end{array}$ & $.511^{* *}$ & 1 \\
\cline { 2 - 4 } & Sig. (2-tailed) & .000 & \\
\cline { 2 - 4 } & $\mathrm{N}$ & 77 & 77 \\
\hline
\end{tabular}

**. Correlation is significant at the 0.01 level (2-tailed).

The relationship between anti-corruption plan and integrity was investigated using Pearson product-moment correlation coefficient. Preliminary analyses were performed to ensure no violation of the assumptions of normality, linearity, and homoscedasticity. There was a strong, positive correlation between the two variables, $r=0.511, n=77, p<0.01$. The more implementation of strategies and initiatives in the anti-corruption plan, the more integrity among public sector employees in Malaysia.

The Pearson correlation in this data is 0.511 , which is then squared equals 26.11 percent shared variance. The anti-corruption plan helps to explain more than 26 percent of the variance in respondents' scores on integrity. When compared to many of the research in the social sciences, this is a respectable amount of variance addressed.

Then, the correlation analysis is used to compare the strength of the correlation coefficients for two separate groups. This analysis looks at the relationship between NACP 
strategies \& initiatives and NACP aspiration for management \& professionals and supporting staff, separately.

Table 4: Pearson correlation test between NACP strategies \& initiatives and NACP aspiration with a different job position

\begin{tabular}{|c|c|c|c|c|}
\hline Job position & & & $\begin{array}{l}\text { NACP } \\
\text { strategies \& } \\
\text { initiatives }\end{array}$ & $\begin{array}{l}\text { NACP } \\
\text { aspiration }\end{array}$ \\
\hline \multirow[t]{6}{*}{$\begin{array}{l}\text { Supporting } \\
\text { staff }\end{array}$} & \multirow[t]{3}{*}{$\begin{array}{l}\text { NACP strategies } \\
\text { \& initiatives }\end{array}$} & $\begin{array}{l}\text { Pearson } \\
\text { Correlation }\end{array}$ & 1 & $.921^{* *}$ \\
\hline & & Sig. (2-tailed) & & .001 \\
\hline & & $\mathrm{N}$ & 8 & 8 \\
\hline & \multirow[t]{3}{*}{ NACP aspiration } & $\begin{array}{l}\text { Pearson } \\
\text { Correlation }\end{array}$ & $.921^{* *}$ & 1 \\
\hline & & Sig. (2-tailed) & .001 & \\
\hline & & $\mathrm{N}$ & 8 & 8 \\
\hline \multirow{6}{*}{$\begin{array}{l}\text { Management } \\
\text { and } \\
\text { professionals }\end{array}$} & \multirow[t]{3}{*}{$\begin{array}{l}\text { NACP strategies } \\
\text { \& initiatives }\end{array}$} & $\begin{array}{l}\text { Pearson } \\
\text { Correlation }\end{array}$ & 1 & $.706^{* *}$ \\
\hline & & Sig. (2-tailed) & & .000 \\
\hline & & $\mathrm{N}$ & 69 & 69 \\
\hline & \multirow[t]{3}{*}{ NACP aspiration } & $\begin{array}{l}\text { Pearson } \\
\text { Correlation }\end{array}$ & $.706^{* *}$ & 1 \\
\hline & & Sig. (2-tailed) & .000 & \\
\hline & & $\mathrm{N}$ & 69 & 69 \\
\hline
\end{tabular}

**. Correlation is significant at the 0.01 level (2-tailed).

From the output in Table 4, the correlation between NACP strategies \& initiatives and NACP aspiration for management \& professionals indicated with correlation coefficient, $r=0.706$, while for supporting staff it was slightly higher, $r=0.921$. The significance levels reported for management \& professionals: Sig. $=0.000$ and supporting staff: Sig $=0.001$ provide a test of the null hypothesis that the correlation coefficient in the population is 0 . The $r$ values for the two groups are considered to have been derived from random samples, and the two groups of samples are unrelated (not the same participants tested twice). The two groups' scores are considered to have a normal distribution.

Other than that, correlation analysis is used to compare the strength of the correlation coefficients between group and variables. The analysis below looks at the relationship between integrity in organizational operation and confidentiality in an organization with different scopes of job, separately. 
INTERNATIONAL JOURNAL OF ACADEMIC RESEARCH ECONOMICS AND MANAGEMENT SCIENCES Vol. 10, No. 3, 2020, E-ISSN: 2226-3624 @ 2020 HRMARS

Table 5: Pearson correlation test between integrity in organizational operation and confidentiality in organization with a different scope of the job

\begin{tabular}{|c|c|c|c|c|}
\hline Scope of job & & & $\begin{array}{l}\text { Integrity in } \\
\text { organizationa } \\
\text { I operation }\end{array}$ & $\begin{array}{l}\text { Confidentialit } \\
\text { y in } \\
\text { organization }\end{array}$ \\
\hline \multirow[t]{6}{*}{$\begin{array}{l}\text { Core business } \\
\text { and development }\end{array}$} & \multirow{3}{*}{$\begin{array}{l}\text { Integrity in } \\
\text { organizational } \\
\text { operation }\end{array}$} & $\begin{array}{l}\text { Pearson } \\
\text { Correlation }\end{array}$ & 1 & $.564^{* *}$ \\
\hline & & Sig. (2-tailed) & & .000 \\
\hline & & $N$ & 37 & 37 \\
\hline & \multirow[t]{3}{*}{$\begin{array}{l}\text { Confidentiality } \\
\text { in organization }\end{array}$} & $\begin{array}{l}\text { Pearson } \\
\text { Correlation }\end{array}$ & $.564^{* *}$ & 1 \\
\hline & & Sig. (2-tailed) & .000 & \\
\hline & & $\mathrm{N}$ & 37 & 37 \\
\hline \multirow[t]{6}{*}{$\begin{array}{l}\text { Regulatory and } \\
\text { enforcement }\end{array}$} & \multirow{3}{*}{$\begin{array}{l}\text { Integrity in } \\
\text { organizational } \\
\text { operation }\end{array}$} & $\begin{array}{l}\text { Pearson } \\
\text { Correlation }\end{array}$ & 1 & .500 \\
\hline & & Sig. (2-tailed) & & .312 \\
\hline & & $\mathrm{N}$ & 6 & 6 \\
\hline & \multirow[t]{3}{*}{$\begin{array}{l}\text { Confidentiality } \\
\text { in organization }\end{array}$} & $\begin{array}{l}\text { Pearson } \\
\text { Correlation }\end{array}$ & .500 & 1 \\
\hline & & Sig. (2-tailed) & .312 & \\
\hline & & $\mathrm{N}$ & 6 & 6 \\
\hline \multirow[t]{6}{*}{$\begin{array}{l}\text { Finance and } \\
\text { procurement }\end{array}$} & \multirow{3}{*}{$\begin{array}{l}\text { Integrity in } \\
\text { organizational } \\
\text { operation }\end{array}$} & $\begin{array}{l}\text { Pearson } \\
\text { Correlation }\end{array}$ & 1 & .600 \\
\hline & & Sig. (2-tailed) & & .116 \\
\hline & & $\mathrm{N}$ & 8 & 8 \\
\hline & \multirow[t]{3}{*}{$\begin{array}{l}\text { Confidentiality } \\
\text { in organization }\end{array}$} & $\begin{array}{l}\text { Pearson } \\
\text { Correlation }\end{array}$ & .600 & 1 \\
\hline & & Sig. (2-tailed) & .116 & \\
\hline & & $\mathrm{N}$ & 8 & 8 \\
\hline \multirow[t]{6}{*}{ Administrative } & \multirow{3}{*}{$\begin{array}{l}\text { Integrity in } \\
\text { organizational } \\
\text { operation }\end{array}$} & $\begin{array}{l}\text { Pearson } \\
\text { Correlation }\end{array}$ & 1 & $.466^{*}$ \\
\hline & & Sig. (2-tailed) & & .033 \\
\hline & & $\mathrm{N}$ & 21 & 21 \\
\hline & \multirow[t]{3}{*}{$\begin{array}{l}\text { Confidentiality } \\
\text { in organization }\end{array}$} & $\begin{array}{l}\text { Pearson } \\
\text { Correlation }\end{array}$ & $.466^{*}$ & 1 \\
\hline & & Sig. (2-tailed) & .033 & \\
\hline & & $\mathrm{N}$ & 21 & 21 \\
\hline \multirow[t]{3}{*}{ Other } & \multirow{3}{*}{$\begin{array}{l}\text { Integrity in } \\
\text { organizational } \\
\text { operation }\end{array}$} & $\begin{array}{l}\text { Pearson } \\
\text { Correlation }\end{array}$ & 1 & $.919^{*}$ \\
\hline & & Sig. (2-tailed) & & .028 \\
\hline & & $\mathrm{N}$ & 5 & 5 \\
\hline
\end{tabular}


Table 5: Pearson correlation test between integrity in organizational operation and confidentiality in organization with a different scope of the job

\begin{tabular}{llll|l} 
Scope of job & & $\begin{array}{l}\text { Integrity in } \\
\text { organizationa } \\
\text { Ioperation }\end{array}$ & $\begin{array}{l}\text { Confidentialit } \\
\text { in } \\
\text { organization }\end{array}$ \\
\hline & $\begin{array}{l}\text { Confidentiality } \\
\text { in organization }\end{array}$ & $\begin{array}{l}\text { Pearson } \\
\text { Correlation }\end{array}$ & $1919^{*}$ & 1 \\
\cline { 2 - 4 } & Sig. (2-tailed) & .028 & 5 \\
\hline & $\mathrm{N}$ & 5 & 5 \\
\hline
\end{tabular}

**. Correlation is significant at the 0.01 level (2-tailed).

*. Correlation is significant at the 0.05 level (2-tailed).

From the output in Table 5, the correlation between integrity in organizational operation and confidentiality in organization for finance and procurement is slightly higher correlation coefficient, $r=0.600$, compared to job scope in core business \& development $(r=0.564)$, regulatory \& enforcement $(r=0.500)$ and administrative $(r=0.466)$. The remaining number in the other group $(r=0.919)$ represents various kinds of job descriptions related such as military, international relations, and others.

\section{Conclusion and Recommendations}

In many countries, fighting corruption and fostering integrity has become a fundamental part of government reform. This is applicable in Malaysia as well. The vision's success is dependent on the establishment of political, social, and economic environments that leads to rapid and sustainable growth. These include policies, strategies, and initiatives to enable effective governance based on integrity to maintain peace and social stability. Integrity and strong governance will increase people's trust in both public and private institutions. The adoption of strong integrity principles can help to strengthen governance. The incorporation of core values such as trust, honesty, and a sense of obligation in carrying out responsibilities would help to prevent leaks and corrupt practices, ultimately increasing public trust in government organizations. This is one of the guiding principles stated in Share Prosperity Vision 2030, in the context of the country's long-term plans to drive economic achievement, raise people's standard of living, and solidify unity.

In a global context, the discriminatory nature of corruption means that the poor and marginalized are negatively affected by the way corruption suppresses economic growth, increases inequality, and skews resource distribution. Societies all over the world may alleviate poverty and realize the benefits of healthy, safe, and educated citizenry by implementing efficient anti-corruption procedures. Fighting corruption is critical to ensuring the success of the "leave no one behind" principle, which is at the heart of the SDGs and the 2030 Agenda. With the presence of discipline and strength, it is correct to say that integrity exists within an individual. In the political realm, noble values are prerequisites for the integrity of a government's machinery, the public's perception of transparency, and the barometer for an individual's trust. As a result, the effort to improve integrity and best governance requires the commitment of all 
stakeholders in the public sector, including officers, staff, and organizations, to follow all rules, regulations, and best practices. Leadership by example is a powerful tool for creating a society where no one tolerates corruption. Leaders of the country must demonstrate their commitment to fighting corruption from the start, with various sectors, organizations, and family units in the community at large. It must be deeply rooted in the minds of all Malaysians that if we are to achieve the status of a developed country, we must fight corruption.

\section{Contribution of The Study}

This research contributes in enriching the body of knowledge on integrity in Malaysia, it has made contributions to the literature on managing organizational issues in Malaysia. Moreover, the high rate of corruption justifies the need for effective methods to improve the integrity among public sector employees in Malaysia. Hence, the outcome of this research will assist policymakers to achieve zero corruption in Malaysia. Finally, this research carries values to the Sustainable Development Goals (SDG-16) in enhancing the policy to substantially reduce bribery and corruption in all their forms.

\section{Acknowledgments}

I would like to express my special thanks of gratitude to Universiti Teknologi Malaysia (UTM) who gave me this golden opportunity to do this wonderful paper under the Encouragement Research grants (PY/2020/04096), as well as other research grant (PY/2021/01847). I am thankful to UTM, I came to know about so many new things that helped me in doing a lot of publications.

\section{Conflicts of interest}

The author declares no conflicts of interest.

\section{References}

Abdul Rahim, R., Mohd Amin, A., and Mohd Razali, N. T. (2020). Scenario planning for development of a national anti-corruption framework. Foresight, 9: 1-12. DOI 10.1108/FS04-2020-0040

Alam, M. M., Johari, R. J., and Said, J. (2018). An empirical assessment of employee integrity in the public sector of Malaysia. International Journal of Ethics and Systems, 34 (4): 458-471.

Alam, M. M., Said, J., and Abd Aziz, M. A. (2019). Role of integrity system, internal control system and leadership practices on the accountability practices in the public sectors of Malaysia. Social Responsibility Journal, 15 (7): 955-976.

Aziz, M.A.A., Rahman, H.A., Alam, M.M. \& Said, J. (2015). Enhancement of the accountability of public sectors through integrity system, internal control system, and leadership practices: a review study. Procedia Economics and Finance, 28: 163-169.

Aziz, M.A.A., Said, J. \& Alam, M.M. (2015). Assessment of the practices of internal control system in the public sectors of Malaysia. Asia-Pacific Management Accounting Journal, 10 (1): 4362.

Bandhold, M.L. (2003). Scenario Planning: The Link between Future and Strategy, New York: Palgrave Macmillan.

Bauman, D.C. (2013). Leadership and the three faces of integrity. The Leadership Quarterly, 24 (3): 414-426. 
Jones, M. (2009). Governance, integrity, and the police organization. Policing: An International Journal of Police Strategies \& Management, 32 (2): 338-350.

Kapeli, N. S. and Mohamed, N. (2015). Insight of Anti-Corruption Initiatives in Malaysia. Procedia Economics and Finance, 31: $525-534$.

Kaptein, M. and Avelino, S. (2005). Measuring corporate integrity: a survey-based approach. Corporate Governance, 5 (1): 45-54.

Kolthoff, E., Erakovich, R. \& Lasthuizen, K. (2010). Comparative analysis of ethical leadership and ethical culture in local government: the USA, The Netherlands, Montenegro and Serbia. International Journal of Public Sector Management, 23 (7): 596-612.

Maizatul, A.K., Alam, M.M. \& Said, J. (2016). Empirical assessment of the good governance in the public sectors of Malaysia. Economics \& Sociology, 9 (4): 289-304.

Mcdermott, C. L., Acheampong, E., \& Arora-Jonsson, S. (2019) SDG 16: Peace, Justice and Strong Institutions - A Political Ecology Perspective. In P. Katila, C. Pierce Colfer, W. De Jong, G. Galloway, P. Pacheco, \& G. Winkel (Eds.), Sustainable Development Goals: Their Impacts on Forests and People (pp. 510-540). Cambridge: Cambridge University Press.

Mohamed, I. S., Alykallam, A., Othman, R., Omar, N., \& Abdul Rahman, S. (2017). Issues of Integrity and Efforts for Improvement in Malaysian Local Authorities. Proceedings of Global Business and Social Science Research Conference, Melbourne, Australia.

National Centre for Governance, Integrity, and Anti-Corruption (GIACC) (2019). National AntiCorruption Plan 2019 - 2023. Putrajaya: Prime Minister's Department.

Palanski, M. E., \& Yammarino, F. J. (2007). Integrity and leadership: Clearing the conceptual confusion. European Management Journal, 25(3): 171-184.

Rahim, A. N. A. A., and Omar, K. (2017). Looking into Working Environment, Integrity and Religiosity as Enhancement for Employee's Job Performance in Malaysia. Journal of Engineering and Applied Sciences, 12(6): 1551-1557.

Rosli, M. H., Abd Aziz, M. A., Mohd, F. and Said, J. (2015). Integrity Systems in Malaysian Public Sector: An Empirical Finding. Procedia Economics and Finance, 28: 260 - 265.

Said, J., Alam, M. M. and Khalid, M. A. (2016). Relationship between good governance and integrity system Empirical study on the public sector of Malaysia. Humanomics, 32 (2): 51171.

Sajari, A., Haron, H. and Ismail, I. (2019). Level of Ethics and Integrity: Case Studies of Malaysian Public Sector Organizations. UMP Institutional Repository: 1-20.

Siddiquee, N. A. (2011). Approaches to Fighting Corruption and Managing Integrity in Malaysia: A Critical Perspective. Journal of Administrative Science, 8 (1): 47-74.

Siddiquee, N.A. (2006). Public management reform in Malaysia: recent initiatives and experiences. International Journal of Public Sector Management, 19 (4): 339-358.

Sitheravellu, C. S. (2021). Drop in Malaysia's corruption perception ranking worrisome. New Straits Times; Retrieved 2021, from: https://www.nst.com.my/opinion/letters/2021/01/661540/drop-malaysias-corruptionperception-ranking-worrisome

Six, F. E., \& Hubert, L. W. (2008). Judging a public official's integrity. Ethics and Integrity of Governance: Perspectives across Frontier: 65-82.

Timilsina, A. R. (2019) Moving from commitment to action: Integration of Anti-corruption in Sustainable Development Goals. UN System Staff College. Retrieved 2021, from: 
https://www.unssc.org/news-and-insights/blog/moving-commitment-action-integrationanti-corruption-sustainable-development/

Trevinyo-Rodríguez, R.N. (2007). Integrity: a systems theory classification. Journal of Management History, 13 (1): 74-93.

Yusoff, A., Abdul Rashid, M and Samsuddin, M. N. (2019). Integrity Among Civil Servant in Malaysian Government Office. EAI 2019: 11-19. DOI 10.4108/eai.10-9-2019.2289404

\section{Appendix}

\section{Test of reliability}

\begin{tabular}{|l|l|l|}
\hline \multicolumn{2}{|l|}{ Reliability Statistics } \\
\hline & $\begin{array}{l}\text { Cronbach's } \\
\text { Alpha Based } \\
\text { on } \\
\text { Cronbach's } \\
\text { Alpha }\end{array}$ & $\begin{array}{l}\text { Standardized } \\
\text { Items }\end{array}$ \\
\hline .935 & .941 & N of Items \\
\hline
\end{tabular}

\section{Item Statistics}

\begin{tabular}{|c|c|c|c|}
\hline & Mean & $\begin{array}{l}\text { Std. } \\
\text { Deviation }\end{array}$ & $\mathrm{N}$ \\
\hline $\begin{array}{l}\text { My department frequently benchmarks its } \\
\text { integrity and ethics }\end{array}$ & 4.18 & .663 & 77 \\
\hline $\begin{array}{l}\text { My department considers managing integrity } \\
\text { an essential leadership competency }\end{array}$ & 4.31 & .730 & 77 \\
\hline $\begin{array}{l}\text { My department fully integrates the integrity } \\
\text { and ethics aspect into all organizational } \\
\text { operations }\end{array}$ & 4.35 & .721 & 77 \\
\hline $\begin{array}{l}\text { My department provides concrete guidance for } \\
\text { integrity and how to address it }\end{array}$ & 4.05 & .872 & 77 \\
\hline $\begin{array}{l}\text { My department can easily identify the integrity } \\
\text { and ethics leader among top managers }\end{array}$ & 3.86 & .956 & 77 \\
\hline $\begin{array}{l}\text { My department provides policies and } \\
\text { guidelines for disciplinary action and rewards } \\
\text { on its integrity and ethics are regarded as best } \\
\text { practice }\end{array}$ & 3.86 & .996 & 77 \\
\hline $\begin{array}{l}\text { My department publishes an annual report } \\
\text { about integrity and ethics }\end{array}$ & 3.04 & 1.240 & 77 \\
\hline $\begin{array}{l}\text { My department respects the confidentiality of } \\
\text { the ethics advisory process at all levels of the } \\
\text { organization }\end{array}$ & 4.06 & .833 & 77 \\
\hline
\end{tabular}


INTERNATIONAL JOURNAL OF ACADEMIC RESEARCH ECONOMICS AND MANAGEMENT SCIENCES Vol. 10, No. 3, 2020, E-ISSN: 2226-3624 @ 2020 HRMARS

\section{Item Statistics}

\begin{tabular}{|c|c|c|c|}
\hline & Mean & $\begin{array}{l}\text { Std. } \\
\text { Deviation }\end{array}$ & $\mathrm{N}$ \\
\hline $\begin{array}{l}\text { My department formally evaluates its ethics } \\
\text { training for effectiveness and constantly } \\
\text { updates and improves }\end{array}$ & 3.81 & 1.089 & 77 \\
\hline $\begin{array}{l}\text { My department promotes transparency in } \\
\text { connection with all of its activities }\end{array}$ & 4.01 & .803 & 77 \\
\hline $\begin{array}{l}\text { My department's supervisors and managers } \\
\text { receive integrity and ethics training on how to } \\
\text { recognize and prevent retaliation }\end{array}$ & 3.61 & 1.066 & 77 \\
\hline $\begin{array}{l}\text { My department supports and assists other } \\
\text { departments in their integrity and ethics }\end{array}$ & 3.81 & 1.064 & 77 \\
\hline $\begin{array}{l}\text { My department promotes integrity conduct as } \\
\text { part of its activities }\end{array}$ & 4.06 & .879 & 77 \\
\hline
\end{tabular}

